\title{
Morphological sexual maturity of the freshwater anomuran crab Aegla parana (Crustacea, Decapoda, Aeglidae) from Negro River Sub-basin, Upper Iguaçu Basin, southern Brazil
}

\author{
Ana M. Schafaschek (D) \& Setuko Masunari (D)
}

Received 29 January 2019

Accepted 8 June 2019

Published 5 August 2019

DOI 10.1590/1678-4766e2019029

\begin{abstract}
The carapace length (CL) at the onset of morphological sexual maturity (MSM) in Aegla parana Schmitt, 1942 was estimated in a population located at Negro River Sub-basin, Upper Iguaçu Basin, southern Brazil. The animals were captured with Surber net and with baited traps in Negro River and in its tributary Totó River, in December/2017, June and July/2018. Carapace length of each individual was measured from the tip of the rostrum to the posterior margin of the carapace, with a digital caliper or under a digital microscope. Length of the major cheliped propodus (LMAP) of males and width of the abdomen (LA) of females were measured for relative growth analysis. The CL at the onset of MSM was estimated as the inflection points on the scatter plots with the REGRANS program. In Negro River, 107 males (CL range 6.90- $50.25 \mathrm{~mm}$ ) and 95 females (10.37-39.36 mm) were obtained, while in Toto River, 225 males (4.92-25.65 mm) and 160 females (5.18- $26.45 \mathrm{~mm}$ ). MSM is attained by males at $23.15 \mathrm{~mm}$ CL and females at $17.85 \mathrm{~mm} \mathrm{CL}$. The smallest ovigerous female measured $19.00 \mathrm{~mm} \mathrm{CL}$. Aegla parana reaches the highest maximum size and males attain MSM with the highest $\mathrm{CL}$ value among the known species of the genus.
\end{abstract}

KEYWORDS. Relative growth, Regrans, Major cheliped propodus, Abdomen.

RESUMO. Maturidade sexual morfológica do caranguejo anomuro Aegla parana (Crustacea, Decapoda, Aeglidae) da sub-bacia do Rio Negro, bacia do Alto Iguaçu, sul do Brasil. O comprimento da carapaça (CL) no início da maturidade sexual morfológica (MSM) em Aegla parana Schmitt, 1942 foi estimado em uma população que ocorre na Sub-bacia do Rio Negro, Bacia do Alto Iguaçu, sul do Brasil. Os animais foram capturados com rede Surber e com armadilhas iscadas no Rio Negro e no seu afluente Rio Totó, em dezembro/2017, junho e julho/2018. Cada indivíduo teve o CL medido da ponta do rostro até a margem posterior da carapaça, com um paquímetro digital ou sob um microscópio digital. O comprimento do propódo do maior quelípodo (LMAP) dos machos e a largura do abdômen (AW) das fêmeas foram medidos para a análise de crescimento relativo. O CL de início da MSM foi estimado como o ponto de inflexão no gráfico de dispersão com o programa REGRANS. No Rio Negro, 107 machos (amplitude de variação do CL: 6,90-50,25 mm CL) e 95 fêmeas (10,37-39,36 mm CL) foram obtidos, enquanto no Rio Totó, 225 machos (4,92-25,65 mm CL) e 160 fềmeas (5,18-26,45 mm CL). MSM é atingido por machos com 23,15 mm CL e fêmeas com 17,85 mm CL. A menor fêmea ovígera mediu 19,00 mm CL. Aegla parana atinge o maior tamanho máximo e os machos atingem MSM com o maior valor de CL entre as espécies conhecidas do gênero.

PALAVRAS-CHAVE. Crescimento relativo, Regrans, Própodo da maior quela, Abdômen.

Aegla Leach, 1820 is the only living genus of the family Aeglidae and its lifecycle is entirely restricted to freshwater environments of southern South America. This genus is composed of 87 species (SANTos et al., 2017; PÁEZ et al., 2018; JARA et al., 2018). Aeglids are animals with a high degree of endemism, making some species highly vulnerable or endangered.

In addition, species with wide distribution, although classified as little threatened, may constitute a complex of species (BRASIL, 2016). Taxonomic rearrangement of these species complex groups, recognition of several new species, would certainly have direct impact in the conservation status originally assessed for any of these groups, as the distribution of each of these species is restricted to their respective typelocality (MorAEs et al., 2016).
Aegla parana Schmitt, 1942 is distributed along Iguaçu Basin $\left(62,000 \mathrm{~km}^{2}\right)$ between the southern Paraná State and the northern Santa Catarina State and along south of Paraná River, having as type locality the Negro River, located on west side of Serra do Mar mountains, separating the states of Santa Catarina and Paraná until it empties into the Iguaçu River. In spite of the relatively wide geographical distribution of the species, studies on its biology are restricted to the reproductive cycle in the population living in Palmital River in the municipality of União da Vitória, Paraná State (GrABOWSKI et al., 2013). Although considered currently "as least concern species" (LC) by PÉREZ-LosADA et al. (2009), future of $A$. parana is uncertain if conservation measures are not implemented in the present study area. Negro River flows between some municipalities as of Mafra, Santa Catarina 
State and Rio Negro, Paraná State, that discharge organic waste into its water, and its tributaries run through a rural area and are submitted to inflow of herbicides and fertilizers. Study the reproductive ecology (reproductive seasonality, recruitment, growth, ontogeny, dimorfism), behavior of food manipulation and agonistic actions are important to know the species and stipulate conservation actions

Data on sexual maturity as well as other reproductive traits are essential important to understand the life cycle (reproductive biology, population structure and dynamics in aeglids), essential for establishment of management policies for the preservation of endangered species (AMARo PINHEIRO \& Fransozo, 1998; Bueno \& Shimizu, 2009; Copatti et al., 2015)

In crustaceans the occurrence of the pubertal moult is an indication that the animal has reached MSM. From this molting, more pronounced growth may occur in certain body dimensions in relation to the overall body size (relative growth), and it constitutes a source of sexual dimorphism in adults. The points of a scatter plot of dimensions of these body parts vs body size can show an abrupt change in the trend that is called inflection point, and it will segregate two groups of points corresponding to juveniles and adults (HARTNOLL, 1978).

In most decapod crustaceans changes in trend of relative growth produce adult males with enlarged chela which is advantageous in fighting for and attraction of females, and adult females with enlarged abdomen that favors accommodation of egg mass (HARTNOLL, 1974). This pattern has been observed in the following aeglid crabs: Aegla longirostri Bond Buckup \& Buckup, 1994 (ColPo et al., 2005), Aegla uruguayana Schmitt, 1942 (VIAU et al., 2006), Aegla franca Schmitt, 1942 (Bueno \& Shimizu, 2009), Aegla platensis Schmitt, 1942 (OliveIra \& SANTOS, 2011), Aegla manuniflata Bond-Buckup \& Santos, 2009 (Trevisan \& Santos, 2012), Aegla marginata Bond-Buckup \& Buckup, 1994 (Silva et al., 2016), Aegla georginae Santos \& Jara, 2013 (Cоратті et al., 2015), Aegla castro Schmitt, 1942 (TAKANo et al., 2016) and Aegla marginata (ADAM et al., 2018). Each population has own size of onset of MSM.

Considering the importance of understanding the biological patterns of the group for future projects on conservation purpose, this study aims to estimate the size of onset of MSM for understanding aeglid biology of males and females of a population of $A$. parana living in Negro River Sub-basin, type locality of the species and quoted only from the description article of the species (see SchmitT, 1942), based on their relative growth.

\section{MATERIAL AND METHODS}

Collection of aeglids. The aeglids were obtained from Rio Negro River and from its tributary Totó River, Iguaçu River Basin, southern Brazil. Five collection points were established along a $28-\mathrm{km}$ long mid section of Negro River that covers the urban and rural area of the municipalities of Rio Negro, Paraná state, and Mafra, Santa Catarina state (between $26^{\circ} 08^{\prime} 07.6^{\prime \prime} \mathrm{S}, 4^{\circ} 44^{\prime} 59.8^{\prime \prime} \mathrm{W}$ and $26^{\circ} 03^{\prime} 04.3^{\prime}$ 'S , 49 $\left.58^{\prime} 38.8^{\prime \prime} \mathrm{W}\right)$. Another five collection points were established along the entire course of Totó River (between $26^{\circ} 09^{\prime} 43.7^{\prime \prime} \mathrm{S}, 49^{\circ} 46^{\prime} 27.7^{\prime \prime} \mathrm{W}$ and $26^{\circ} 08^{\prime} 34.2^{\prime \prime} \mathrm{S}$, $49^{\circ} 45^{\prime} 31.4^{\prime \prime} \mathrm{W}$ ), that is $6.61 \mathrm{~km}$ long and runs through the rural area of Mafra.

The animals were captured with a Surber sampler $(500 \mu \mathrm{m}$ mesh) and baited lobster-pot type traps locally called "covo", in December 2017, June and July 2018. Ten baited traps were set and overnighted for 10-12 hours in each collection point and were inspected for captured animals in the next morning. Since these traps selectively capture large aeglids, collections were complemented with Surber sampler positioned against the direction of the water flow to obtain juveniles that were not collected by traps. The sampling effort for Surber samples was two people for one hour. The collected specimens were transported to the laboratory in cooled box and frozen until laboratory procedures.

Laboratory procedure and statistical analysis. The aeglids were sexed based on the position of the gonopore openings that are located in coxae of the third pair of pereiopods in females and in the fifth pair of pereiopods in males (Martin \& AbELE, 1988). Males and females had their carapace length (CL) measured from the apex of the rostrum to the mid-posterior border, with a digital caliper (individuals $>20 \mathrm{~mm} \mathrm{CL}$ ) or with Dino-Lite Pro AM413 digital microscope which measures the digital image in micrometric scale (individuals $\leq 20 \mathrm{~mm} \mathrm{CL}$ ). The length of the major cheliped propodus (LMAP) of males was measured from the apex of pollex to the posterior end of the outer margin. In females, the abdomen width (AW) between the lateral margins of the second abdominal somite was measured. These body parts were selected for the present study because they are related to reproductive activities and tend to show change in growth rate (relative growth) during the transition from the immature to the adult stages (Viau et al., 2006; Bueno \& Shimizu, 2009, Almerão et al., 2010). The individuals with damaged rostrum, with one or both chelipeds missing or regenerating were excluded from this analysis.

The description of the relative growth, considering CL as the independent variable $(\mathrm{x})$ and the body part dimensions (LMAP, AW) as dependent variables (y) (HuXLEY, 1950), was based on the allometric equation $\mathrm{y}=\mathrm{ax}^{\mathrm{b}}$, linearized to $\log \mathrm{y}=\log \mathrm{a}+\mathrm{b} \log \mathrm{x}$. The values of $a$ (elevation of the lines) and $b$ (allometric coefficient) were estimated by linear regression of $\log Y$ on $\log X$ using the least squares method (HuBER, 1985). The inflection point, which corresponds to the CL at the onset of MSM (Oliveira \& SANTOS, 2011) was calculated using the software REGRANS (PEzzUTO, 1993).

The state of allometry was assessed with a $t$ test on the slope (allometric coefficient), under the null hypothesis $\mathrm{H}_{0}: b=1$ (isometric growth). Rejection of $\mathrm{H}_{0}$ meant that growth was positively $(b>1)$ or negatively $(0<b<1)$ allometric. The slopes and the intercepts were compared 
between development phases of both sexes with an analysis of covariance (ANCOVA, $\alpha=0.05$ ) (SOKAL \& RoHLF, 1979).

\section{RESULTS}

A total of 587 aeglids (255 females and 332 males) were collected, among them 107 males (CL range: 6.90-50.25 $\mathrm{mm}$, mean $\pm \mathrm{SD}: 26.71 \pm 11.64)$ and 95 females (10.37-39.36 $\mathrm{mm}$ CL, mean $\pm \mathrm{SD}: 26.68 \pm 7.28 \mathrm{~mm} \mathrm{CL})$ were obtained from Negro River and 225 males (4.92-25.65 mm CL, mean \pm SD: $9.99 \pm 3.38 \mathrm{~mm} \mathrm{CL})$ and 160 females (5.18-26.45 $\mathrm{mm}$ CL, mean $\pm \mathrm{SD}: 10.02 \pm 3.04 \mathrm{~mm} \mathrm{CL})$, including three ovigerous females with CL ranging from 19.00 to 26.45 $\mathrm{mm}$, from Totó River.

The results of the regressions are in Table I and in Figures 1 and 2. There was a significant difference between slopes (b) for juveniles and adult males in the LMAP x CL $(p<0.0001)$ and for females in the relationship AW x CL ( $p$
$=0.0417)$. Both relationships LMAP vs. CL and AW vs. CL were positively allometric, that is, LMAP and AW increase at a faster rate than CL. The MSM is reached by males with $23.15 \mathrm{~mm}$ CL (Tab. I, Fig. 1) and females with $17.85 \mathrm{~mm}$ CL (Tab. I, Fig. 2). The largest juvenile male measured $22.7 \mathrm{~mm}$ CL, while the smallest adult, $19.27 \mathrm{~mm} \mathrm{CL}$. On the other hand, the largest juvenile female measured 23.90 $\mathrm{mm}$ CL and the smallest adult, $17.85 \mathrm{~mm}$ CL. Most males (75.11\%) of exhibited the left cheliped larger than right one in the present study.

\section{DISCUSSION}

Aegla parana is the largest of the currently known species of the genus that had their population size structure studied so far (maximum $C L$ of males $=50.25 \mathrm{~mm}$ and of females $=39.36 \mathrm{~mm}$ ). The CL at the onset of MSM of $A$. parana is very close to the maximum CL attained by the

Tab. I. Aegla parana Schmitt, 1942. Inflection points, equations of the regressions of the LMAP x CL and AW x CL relationships, with corresponding values of the coefficient of determination and results of tests og allometry status of males and females. LMAP, length of the major propodus; AW, abdomen width; CL, carapace length; JM, juvenile males; AM, adult males; JF, juvenile females; AF, adult females.

\begin{tabular}{|c|c|c|c|c|c|c|c|}
\hline Variable & Sex & $\mathrm{N}$ & $\begin{array}{l}\text { Inflection point } \\
\text { (mm CL) }\end{array}$ & $\begin{array}{c}\text { Equation } \\
(\log \mathrm{y}=\log \mathrm{a}+\mathrm{b} \cdot \log \mathrm{x})\end{array}$ & $\mathrm{r}^{2}$ & $\begin{array}{c}\mathrm{t} \\
(\mathrm{b}=1)\end{array}$ & Allometry \\
\hline \multirow{2}{*}{ LMAP } & $\mathrm{JM}$ & 266 & \multirow{2}{*}{23.15} & $\log \mathrm{LMAP}=-0.4882+1.1642 \log \mathrm{CL}$ & 0.92 & 35.16 & + \\
\hline & $\mathrm{AM}$ & 66 & & $\log \mathrm{LMAP}=-0.7388+1.3665 \log \mathrm{CL}$ & 0.85 & 47.05 & + \\
\hline \multirow{2}{*}{ AW } & $\mathrm{JF}$ & 166 & \multirow{2}{*}{17.85} & $\log \mathrm{AW}=-0.3824+1.1629 \log \mathrm{CL}$ & 0.94 & 31.85 & + \\
\hline & $\mathrm{AF}$ & 89 & & $\log \mathrm{AW}=-0.2640+1.0958 \log \mathrm{CL}$ & 0.92 & 69.88 & + \\
\hline
\end{tabular}

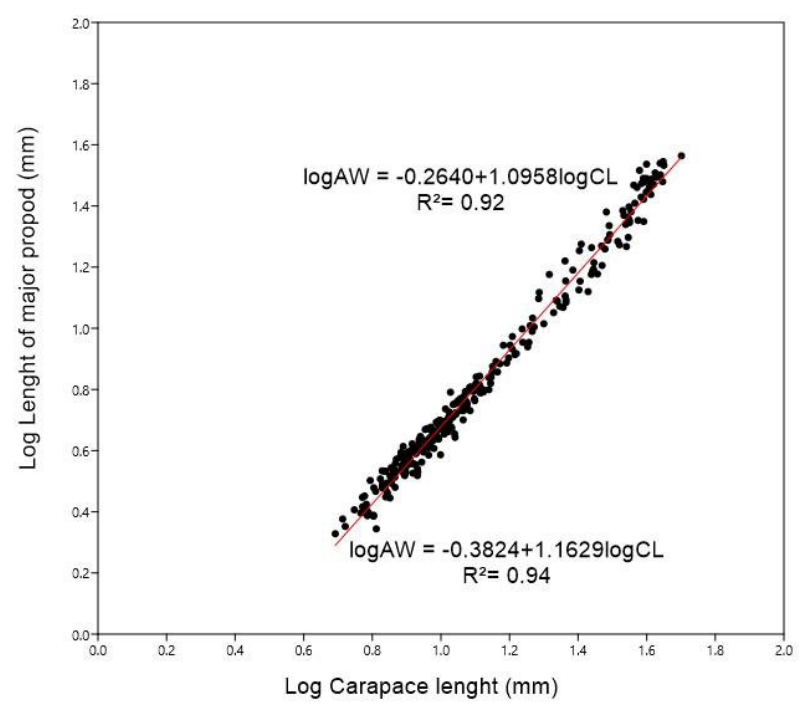

Fig. 1. Aegla parana Schmitt, 1942. Relationship between the length of the major propodus (LMAP) and the carapace length (CL) of the males. The inflection point is at $23.15 \mathrm{~mm}$ CL. Black circles represent juveniles and adults.

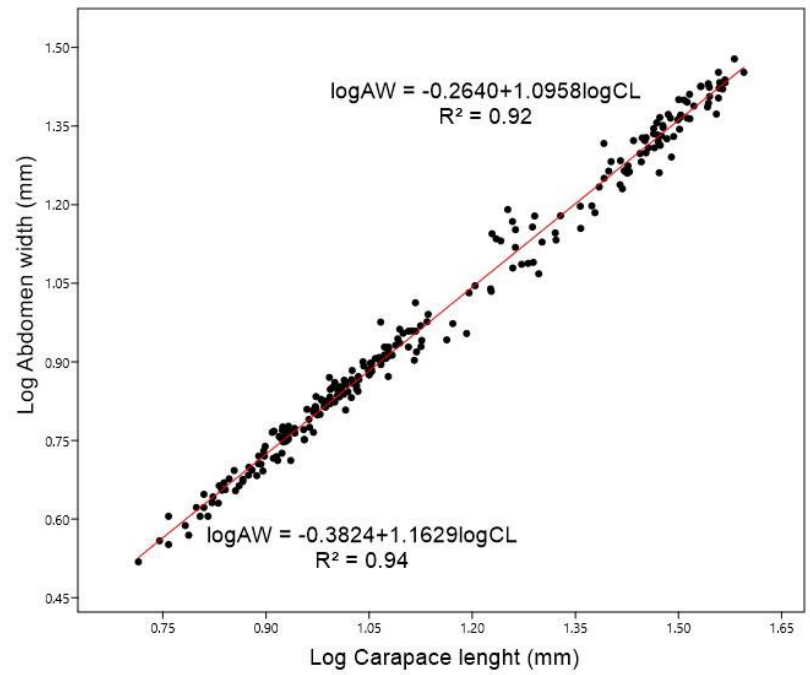

Fig. 2. Aegla parana Schmitt, 1942. Relationship between the abdomen width (AW) and carapace length (CL) of the females. The inflection point is at $17.85 \mathrm{~mm}$ CL. Black circles represent juveniles and adults. 
smallest species, A. marginata (Figs 3, 4). The carapace length (CL) at the onset of morphological sexual maturity (MSM) in aeglids is directly related to the maximum CL reached by the respective species: (Figs 3,4 ). This relationship is described by the linear functions $y=0.3979 x+3.6282, R^{2}$ $=0.8361$ for males $(\mathrm{p}=0.003)$ (Fig. 3) and $y=0.348 x+$ $4.7218, R^{2}=0.8006$ for females $(\mathrm{p}=0.006)$ (Fig. 4). These equations allow estimations of the CL at onset of MSM of aeglid species by knowing its maximum species size.

The size at the onset of maturity correlated with the maximum species size. Oliveira \& SANTOS (2011) estimated that the maturity in Aegla species is reached between approximately 40 and $70 \%$ in relation to the size of the largest sampled individual. TAKANO et al. (2016) estimated the percentage of 38 and $60 \%$, indicating that aeglids tend to attain morphometric maturity by the time they are approximately half as large as the maximum size they reach. The size of each population also influenced by the environmental conditions (OliveIra \& SANTOS, 2011). As in the present study, other works bring the trend of males attaining morphometric maturity to a larger size than females (TAKANO et al., 2016).

In $A$. parana females, it is possible to observe the maturity tendency in relation to the maximum size reached, despite the distinct criteria (functional and morphological) to separate mature and immature. Females from the population of $A$. parana living at Palmital River, Iguaçu Basin, attain the onset of functional maturity in $17.4 \mathrm{~mm} \mathrm{CL}$ and the largest CL for a female was $27.0 \mathrm{~mm}$ (GRABOWSKI et al., 2013), in the present population the smallest ovigerous female had

\section{3}

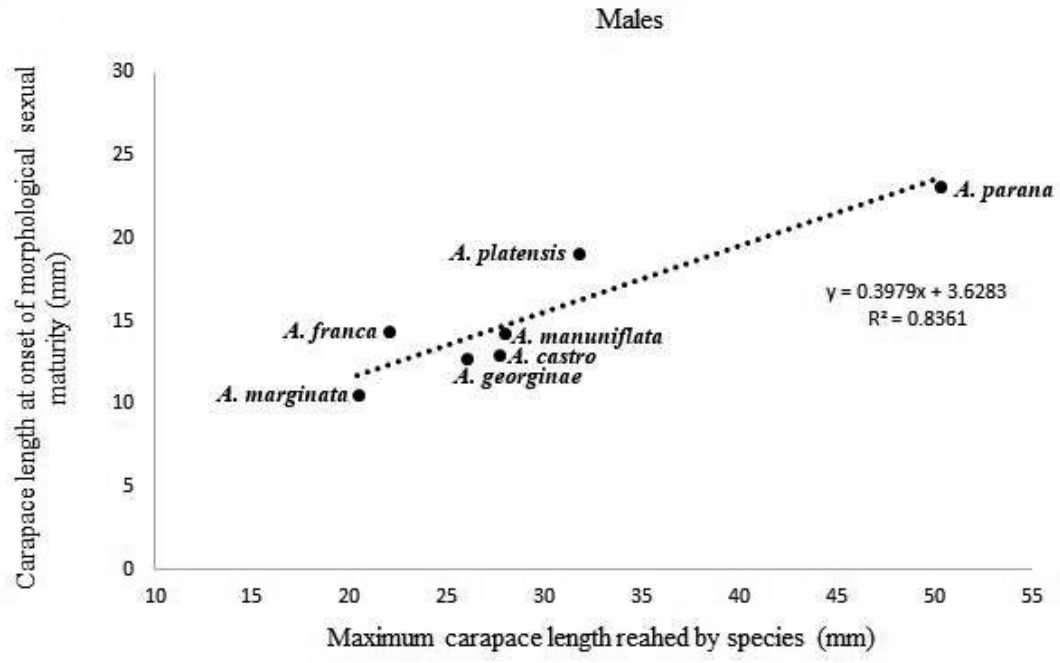

4

Females

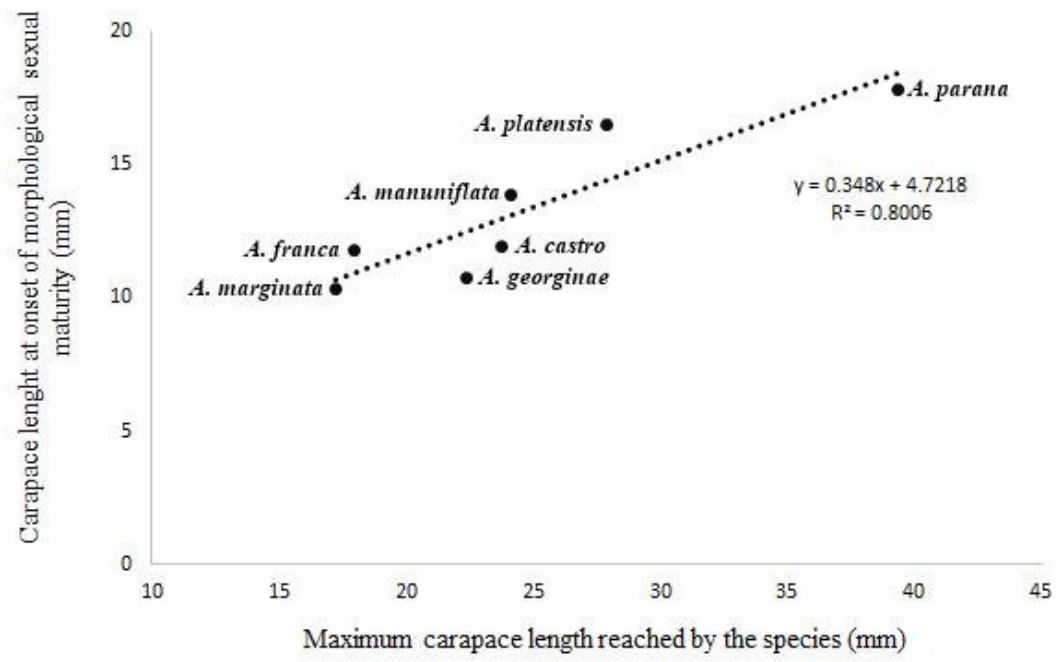

Figs 3, 4. Relationship between the size at the onset of the morphological sexual maturity and the maximum carapace length reached by males (Fig. 3) and females (Fig. 4) of the Aegla species. References: A. franca - Bueno \& Shimizu (2009), A. platensis - Oliveira \& SANTos (2011), A. manuniflata - Trevisan \& Santos (2012), A. georginae - Copatti et al. (2015), A. castro - TaKano et al. (2016), A. marginata - Adam et al. (2018), Aegla parana - present study. 
$19 \mathrm{~mm} \mathrm{CL}$, the onset of MSM is $17.85 \mathrm{~mm}$ and the largest female had quite bigger CL (39.36 mm).

In addition to body size other corporate features are related to a reproductive ecology. In heterochelous decapods, each chelae may be used in different ways, the use of the minor chela is also associated with grooming behavior, while the major chela are associated with reproductive activities as agonistic confrontations, reproductive behavior, to defend receptive females from other males (MARIAPPAN et al., 2000; ViAU et al., 2006; ALMERÃo et al., 2010; TAKANO et al., 2016), in A. uruguayana both chelipeds may participate in specific reproductive tasks (VIAU et al., 2006). On the other hand, the aeglid female's abdomen has a primordial importance for accommodation of eggs during their embryogenesis.

The higher allometry level observed in males (LMAP x CL; $\mathrm{b}=1.36$ ) than in females (AW x CL; $\mathrm{b}=1.09$ ) of $A$. parana in the present study can be explained by the different relationship of the studied dimensions and the body: while males' chelipeds are independent appendages and they are not functionally limited by the size of any body structures, the abdomen is a dimension totally dependent of the sternum morphology. Both (sternum and abdomen) have to function together and any eventual disproportionate increase in AW would reduce the efficiency of body movements and walking (HARTNOLL, 1982).

The larger sized males in relation to females observed in the present study of $A$. parana is known for most Aegla species (BuENo et al., 2016). Causes of size dimorphism that has been suggested by the necessity in directing energy to reproductive events among females, such as eggs incubation, which increases the period between mouting and decreases the growth rates (DíAZ \& CONDE, 1989), males used chelae in aggressive interactions with other males during mating period (VIAU et al., 2006) and lifting and rotating female's body in mating behavior (ALMERÃo et al., 2010). This occurrence of sexual dimorphism in structures which play important roles in sexual interaction might be a strong indication that sexual selection operates on the determination of body size difference between males and females of a population (SHINE, 1989; CoHEN et al., 2011). Mortality, migration, responses to environmental conditions (GONÇALVES et al., 2006), and resource use (SILVA-GONÇALVES et al., 2009) have also been suggested.

Aeglid males have a tendency the left chela to be the largest (or longest) one in relation to the right chela. In $A$. franca, $89.30 \%$ of males are left-handed (BuENo \& SHIMIzU, 2009), in A. castro, they are $72.95 \%$ (TAKANO et al., 2016), and in A. parana, $75.11 \%$ (present study). Other examples of heterochelous aeglids with handedness preponderance of the left chela are mentioned in BAHAMONDE \& LóPEZ (1961), López (1965), Rodrigues \& Hebling (1978), Viau et al. (2006) and OliveIRA \& SANTOS (2011). The meaning of this tendency will be certainly clarified with laboratory experiments on behavior of food manipulation and agonistic actions in A. parana.
Studying a morphological sexual maturity of the species is essential for understanding the functioning of the population, other research is correlated with such data, such as spatial distribution, food preference of size classes and population growth rate.

Finally, further research can be done to better understand the correlation between size of sexual maturity and maximum size, such as environmental and population differences.

Acknowledgments. We are thankful to Coordenação de Aperfeiçoamento de Pessoal de Nível Superior (CAPES) for Master Course scholarship to the first author; to SISbio for collection license No. 161401; to Lucas Schafaschek, Célia Schafaschek, Regina Schafaschek, Márcio Henrique Fernandes and Karine Keler for helping us in the aeglid samplings.

\section{REFERENCES}

Adam, C. L.; Marochi, M. Z. \& Masunari, S. 2018. Ontogenetic shape changes and sexual dimorphism in Aegla marginata Bond-Buckup and Buckup, 1994. Anais da Academia Brasileira de Ciências 90(2):1521-1532.

Almerão, M.; Bond-Buckup, G. \& Mendonça JR., M. S. 2010. Mating behavior of Aegla platensis (Crustacea, Anomura, Aeglidae) under laboratory conditions. Journal of Ethology 28:87-94.

Amaro Pinheiro, M. A. \& Fransozo, A. 1998. Sexual maturity of the specked swimming crab Aranaeus cribrarius (Lamarck, 1818) (Decapoda, Brachyura, Portunidae), in the Ubatuba littoral, São Paulo, Brazil. Crustaceana 71:434-452.

BAHAmonde, N. \& LóPez, M. T. 1961. Estudios biologicos em la poblacion de Aegla laevis laevis (Latreille) de el Monte (Crustacea, Decapoda, Anomura). Investigaciones Zoologicas Chilenas 7:19-58.

BRASIL - Ministério do Meio Ambiente. 2016. Avaliação do risco de extinção dos crustáceos no Brasil: 2010-2014. Itajaí. Disponível em $<$ http://www.icmbio.gov.br/cepsul/images/stories/biblioteca/download/ trabalhos_tecnicos/pub_2016_avaliacao_crustaceos_2010_2014.pdf > . Acesso em 25.03.2019.

Bueno, S. L. S. \& Shimizu, R. M. 2009. Allometric growth, sexual maturity, and adult male chelae dimorphism in Aegla franca (Decapoda: Anomura: Aeglidae). Journal of Crustacean Biology 29:317-328.

Bueno, S. L. S.; Shimizu, R. M.; \& Moraes, J. C. B. 2016. A remarkable anomuran: the taxon Aegla Leach, 1820. Taxonomic remarks, distribution, biology, diversity and conservation. In: KaWAI, I. \& Cumberlidge, N. A global overview of the conservation of freshwater decapod crustaceans. Springer International Publishing, p. 23-64.

Cohen, F. P. A.; Takano, B. F.; Shimizu, R. M. \& Bueno, S. L. S. 2011. Life cycle and population structure of Aegla paulensis (Decapoda: Anomura: Aeglidae). Journal of Crustacean Biology 31:389-395.

Colpo, K. D.; Ribeiro, L. O. \& Santos, S. 2005. Population biology of the freshwater anomuran Aegla longirostri (Aeglidae) from South Brazilian streams. Journal of Crustacean Biology 25:495-499.

Copatti, C. E.; Machado, J. V. D. V. \& Trevisan, A. 2015. Morphological variation in the sexual maturity of three sympatric aeglids in a river in southern Brazil. Journal of Crustacean Biology 35:59-67.

Díaz, H. \& Conde, J. E. 1989. Population dynamics and life history of the mangrove crab Aratus pisonii (Brachyura, Grapsidae) in a marine environment. Bulletin of Marine Science 45:148-163.

Gonçalves, R. S.; Silva-Castiglioni, D. \& Bond-Buckup, G. 2006. Ecologia populacional de Aegla franciscana (Crustacea, Decapoda, Anomura) em São Francisco de Paula, RS, Brasil. Iheringia, Série Zoologia 96:109-114.

Grabowski, R. C.; Santos, S. \& Castilho, A. L. 2013. Reproductive ecology and size of sexual maturity in the anomuran crab Aegla parana (Decapoda: Aeglidae). Journal of Crustacean Biology 33:332-338.

HARTNOLL, R. G. 1974. Variation in growth patterns between some secondary sexual characters in crabs (Decapoda: Brachyura). Crustaceana 27:131136. 
HaRTNOLL, R. G. 1978. The determination of relative growth in Crustacea. Crustaceana 34:281-293.

Hartnoll, R. G. 1982. Growth. In: Bliss, D. E. The Biology of Crustacea, Embriology, Morphology and Genetics. Academic Press v. 2, p.111196.

Huber, M. E. 1985. Allometric growth of the carapace in Trapezia (Brachyura, Xanthidae). Journal of Crustacean Biology 5:79-83.

HuXLey, J. S. 1950. Relative growth and form transformation. Proceedings of the Royal Society London 137:465-469.

Jara, C. G.; Pérez-Losada, M. \& Crandall, K. A. 2018. Aegla chilota, new species of anomuran freshwater crab from Chiloé Island, western Patagonia. Nauplius 26:1-11.

LÓPEZ, M. T. 1965. Estudios biológicos em Aegla oderbrechtti paulensis Schmitt (Crustacea, Decapoda, Anomura). Boletim da Faculdade de Filosofia, Ciências e Letras da Universidade de São Paulo, série Zoologia 25:301-314.

Mariappan, P.; Balasundaram, C. \& Schmitz, B. 2000. Decapod crustacean chelipeds: an overview. Journal of Biosciences 25:301-313.

Martin, J. W. \& Abele, L. G. 1988. External morphology of the genus Aegla (Crustacea: Anomura: Aeglidae). Smithsonian Contributions to Zoology 453:1-46.

Moraes, J. C. B.; Terossi, M.; Buranelli, R. C.; Tavares, M.; Mantelatto, F. L. \& Bueno, S. L. S. 2016. Morphological and molecular data reveal the cryptic diversity among populations of Aegla paulensis (Decapoda, Anomura, Aeglidae), with descriptions of four new species and comments on dispersal routes and conservation status. Zootaxa 4193(1): $1-48$

Oliveira, D. \& Santos, S. 2011. Maturidade sexual morfológica de Aegla platensis (Crustacea, Decapoda, Anomura) no Lajeado Bonito, norte do estado do Rio Grande do Sul, Brasil. Iheringia, Série Zoologia 101:127-130.

Páez, F. P.; Marçal, I. C.; Souza-Shibatta, L.; Gregati, R. A.; Sofia, S. H. \& Teixeira, G. M. 2018. A new specis of Aegla Leach, 1820 (Crustacea, Anomura) from the Iguaçu River basin, Brasil. Zootaxa 4527(3):335-346.
Pérez-Losada, M.; Bond-Buckup, G.; Jara, C. G. \& Crandall, K. A. 2009. Conservation assessment of southern South American freshwater ecoregions on the basis of the distribution and genetic diversity of crabs from the genus Aegla. Conservation Biology 23:692-702.

Pezzuto, P. R. 1993. Regrans: a "basic" program for an extensive analysis of relative growth. Atlântica 15:93-105.

Rodrigues, W. \& Hebling, N. J. 1978. Estudos biológicos em Aegla perobae Hebling and Rodrigues, 1977 (Decapoda, Anomura). Revista Brasileira de Biologia 38(2):383-390.

Santos, S.; Bond-Buckup, G.; Gonçalves, A. S.; Bartholomei-Santos, M. L.; BUCKUP, L. \& JARA, C. G. 2017. Diversity and conservation status of Aegla spp. (Anomura, Aeglidae): an update. Nauplius 25:1-14.

Sснмітт, W. L. 1942. The Species of Aegla, Endemic South American Freshwater Crustaceans. Proceedings of the National Museum 9:431-524.

SHINE, R. 1989. Causes for the evolution of sexual dimorphism: A review of the evidence. The Quarterly Review of Biology 64:419-461.

Silva, A. R.; Wolf, M. R. \& CAStilHo, A. L. 2016. Reproduction, growth and longevity of the endemic South American crab Aegla marginata (Decapoda: Anomura: Aeglidae). Invertebrate Reproduction \& Development 60:1-14.

Silva-Gonçalves, R. S.; Bond-Buckup, G. \& Buckup, L. 2009. Crescimento de Aegla itacolomiensis (Crustacea, Decapoda) em um arroio da Mata Atlântica no sul do Brasil. Iheringia, Série Zoologia 99:397-402.

SoKal, R. R. \& Rohlf, J. F. 1979. Biometry. New York, W. H. Freeman and Company. $887 \mathrm{p}$.

Takano, B. F.; Cohen, F. P. A.; Fransozo, A.; Shimizu, R. M. \& Bueno, S. L. S. 2016. Allometric growth, sexual maturity and reproductive cycle of Aegla castro (Decapoda: Anomura: Aeglidae) from Itatinga, state of São Paulo, southeastern Brazil. Nauplius 24:1-15.

Trevisan, A. \& SANTos, S. 2012. Morphological sexual maturity, sexual dimorphism and heterochely in Aegla manuinflata (Anomura). Journal Crustacean Biology 32:519-527.

Viau, V. E.; López Greco, L. S.; Bond-Buckup, G. \& Rodríguez, E. M. 2006. Size at the onset of sexual maturity in the anomuran crab, Aegla uruguayana (Aeglidae). Acta Zoologica 87:253-264. 